\title{
ANTI-INFLAMMATORY EFFECT OF ZINGIBER OFFICINALE ON SPRAGUE DAWLEY RATS
}

\author{
NDANUSA ABDULLAHI HASSAN, ROHINI KARUNAKARAN*, UMA SANKAR A, KHIN MAR AYE
}

Unit of Biochemistry, Faculty of Medicine, AIMST University, Semeling, Bedong, Malaysia. Email: rohinik23@gmail.com

\author{
Received: 20 November 2016, Revised and Accepted: 05 December 2016
}

\section{ABSTRACT}

Objective: To investigate the anti-inflammatory effect of aqueous extract of Zingiber officinale on carrageenan-induced inflammation on Sprague Dawley (SD) rats.

Methods: SD rats were divided into six of five groups and allowed to acclimatize for 1 week. Inflammation was induced on the animal by injecting the right hand paw with carrageenan ( $0.1 \mathrm{ml}$ of $1 \%)$. Group 1 was given normal saline and served as a control. Group 2 was fed with food and water and served as the carrageenan control. Group 3 was given $200 \mathrm{mg} / \mathrm{kg}$ aqueous extract of ginger, Group 4 with $400 \mathrm{mg} / \mathrm{kg}$ aqueous extract of ginger, and Group 5 with $150 \mathrm{mg} / \mathrm{kg}$ diclofenac sodium (reference drug for inflammation).

Results: The paw edema in carrageenan-induced SD rats was considerably reduced by treating with $400 \mathrm{mg} / \mathrm{kg}$ aqueous ginger extracts when compared to the untreated SD rats $(\mathrm{p}<0.001)$.

Conclusion: This study indicates that aqueous extract of Z. officinale possesses anti-inflammatory properties.

Keywords: Anti-inflammatory, Sprague Dawley rats, Zingiber officinale, Carrageenan, Edema

(C) 2017 The Authors. Published by Innovare Academic Sciences Pvt Ltd. This is an open access article under the CC BY license (http://creativecommons. org/licenses/by/4. 0/) DOI: http://dx.doi.org/10.22159/ajpcr.2017.v10i3.16521

\section{INTRODUCTION}

Inflammation is a body resistance reaction to eradicate or limit the spread of injurious agent and it is a local response of living mammalian tissues to injury [1-3]. There are various mechanisms to an inflammatory reaction, which can contribute to the associated symptoms and tissue injury. Edema, granuloma formation, and leukocyte infiltration signify such components of inflammation. However, it is a defense mechanism. The complex events and mediators involved in the inflammatory reaction can induce or aggravate many reactions [3-5]. According to the WHO report, about $70-80 \%$ of the world's population depend on nonconventional medicine predominantly from herbal sources in their primary health care $[6,7]$. Especially, in developing nations where the cost of consulting a physician and fee of medicine are beyond the edge of most people, thereby the demand is increasing day by day. These drugs are anti-inflammatory and used to ease pain in various conditions including arthritis, muscle, and ligament pains $[8,9]$.

\section{METHODS}

\section{Plant material}

Ginger (Zingiber officinale) rhizomes were collected during March-April 2016 from Sungai petani vegetable market Kedah Malaysia. The plant material was taxonomically identified by a botanist from faculty of Biotechnology at AIMST University Malaysia. (Halia in Malay. Scientifically as Z. officinale). The voucher specimen was maintained in AIMST University, Faculty of Medicine research laboratory for future reference. Z. officinale rhizome was collected and aqueous extract for use in the study.

Preliminary phytochemical screening test for Z. officinale Phytochemical screening of the plant extract was carried out to investigate the present of secondary metabolites such as flavonoid, terpenoids, saponins, tannins, and phenol using standard procedure by Evans method [10].

\section{Test for terpenoids (Salkowski test)}

About $2 \mathrm{ml}$ of chloroform was added to about $1 \mathrm{ml}$ of plant extract. To this mixture, $3 \mathrm{ml}$ of concentrated sulfuric $\left(\mathrm{H}_{2} \mathrm{SO}_{4}\right)$ acid is added carefully without jerking. Development of a reddish brown coloration at the interface indicates the presence of terpenoids.

\section{Test for flavonoids}

To $1 \mathrm{ml}$ of the extract, $5 \mathrm{ml}$ of dilute ammonia is added. In addition, of $1 \mathrm{ml}$ concentrated $\mathrm{H}_{2} \mathrm{SO}_{4}$ a yellow color solution is temporarily produced which indicate the present of flavonoid. As a confirm test for flavonoid, a few drops of $1 \%$ aluminum solution is added to the plant extract and formation of a permanent yellow color solution indicates the presence of flavonoid.

\section{Test for saponins}

To $1 \mathrm{ml}$ of extract, $1 \mathrm{ml}$ of distilled water was added and shaken vigorously; a stable permanent form will develop indicating its presence. The result was positive for the test.

\section{Test for tannins}

About $1 \mathrm{ml}$ of the extract was mixed with $9 \mathrm{ml}$ of distilled water to make up the volume of the solution to $10 \mathrm{ml}$; it was then subjected to boiling in a boiling bath for 5 minutes. After boiling, the mixture was cooled and filtered. To the filtrate, $1.0 \mathrm{ml}$ of $0.1 \%$ ferric chloride is added. This will result in the formation of brownish green or blue-black coloration if tannin was presence.

\section{Test for phenols}

A portion of the extract of the samples was diluted with distilled water in a ratio $1: 4$. Few drops of $10 \%$ ferric chloride solution were added. The appearance of green solution indicates the presence of phenol, which was present.

\section{Experimental animals}

Female SD rats of weighing 160-200 g were procured from registered breeders (Universiti Sains Malaysia) and were housed in a clean polypropylene cages with not more than four animals per cage and maintained under standard laboratory conditions (temperature $25 \pm 2{ }^{\circ} \mathrm{C}$ with dark/light cycle 12/12 hrs) at AIMST University animal house. They were fed with standard pellet diet and water ad libitum. The 
animals were acclimatized to laboratory conditions for 10 days before experiment. All experimental procedures described were reviewed and approved by the Institutional Animal Ethics Committee.

\section{Preparation of extract Z. officinale}

Aqueous ginger extract was prepared from locally available Malaysian ginger roots. Ginger roots (20 g) were peeled and was cut into small pieces and homogenized in $75 \mathrm{ml}$ cold, sterile $0.9 \% \mathrm{NaCl}$ solution, and $25 \mathrm{ml}$ ice-cold water to make the volume $100 \mathrm{ml}$. The homogenization was carried out in a blender for 12 minutes. The homogenized mixture was filtered three times through cheesecloth. The filtrate was centrifuged at $2000 \mathrm{rpm}$ for 10 minutes, the clear supernatant fraction was separated, and volume made up to $100 \mathrm{ml}$ with normal saline. The concentration of this ginger preparation was calculated to have $200 \mathrm{mg} / \mathrm{ml}$ based on the weight of the starting material [11]. The aqueous extract was stored in sample tubes at $-20^{\circ} \mathrm{C}$ until fed to rats.

\section{Acute toxicity}

The acute oral toxicity of aqueous extract of $Z$. officinale, in female Sprague Dawley (SD) rats was studied as per reported method [12]. These extracts were given to three groups $(n=6)$ of animals at concentrations 1000, 1500 and $2000 \mathrm{mg} / \mathrm{kg}$ body weight. The treated animals were kept under observation for 2 days, for mortality and general behavior. No toxic effects were observed until the end of the study.

\section{Evaluation of anti-inflammatory activity}

The rats were divided into five groups $(\mathrm{n}=6)$. Group I served as normal non-inflammation control and all other groups were comprised carrageenan-induced inflammation rats. Group II served as carrageenan control. Groups III and IV received $200 \mathrm{mg} / \mathrm{kg}$ and $400 \mathrm{mg} / \mathrm{kg}$ b.w of $Z$. officinale orally. Group $\mathrm{V}$ received the reference drug diclofenac sodium (150 mg/kg b.w.,) once for $24 \mathrm{hrs}$.

\section{RESULTS}

Preliminarily, the presence of the phytochemicals was assessed to identify the potential constituents present in the extract. The following results show the phytochemical analysis of ethanolic (Table 1) and aqueous (Table 2) extracts of $Z$. officinale.

The results in Table 1 show the presence of flavonoids, saponins, tannins, terpenoids, and phenol in the ethanolic extract of $Z$. officinale. The aqueous extract of $Z$. officinale was also tested for the presence of phytochemicals by the methods described in the materials and methods section. Table 2 shows the presence of phytochemical constituents such as flavonoids, saponins, and terpenoids in the aqueous extract of Z. officinale.

\section{DISCUSSION}

The use of herbal medicines is becoming popular due to toxicity and side effects of allopathic medicines. Medicinal plants play an important role in the development of potent therapeutic agents. There are over 1.5 million practitioners of the traditional medicinal system using medicinal plants in preventive, promotional, and curative applications $[13,14]$. In this study, the results of the preliminary phytochemical screening of both aqueous and ethanolic extracts of Malaysian ginger (Z. officinale) have shown to contain flavonoids, saponins, terpenoids and phenols. As shown in Tables1 and 2, several studies also have shown that $Z$. officinale extracts have substantial amounts of flavonoid, terpenoids, saponins, and phenols [15-17].

To assess the safety of the plant material being used, the toxicity assay with the $Z$. officinale aqueous extracts was carried out. The acute oral toxicity of aqueous extract of $Z$. officinale, in female SD rats was studied with concentrations 1000,1500 and $2000 \mathrm{mg} / \mathrm{kg}$ body weight the treated animals were kept under observation for 2 days, for mortality and general behavior. No toxic effect was observed until the end of the study.

Plants as natural anti-inflammatory agents unlike modern allopathic drugs, which are single active components that target one specific pathway, herbal medicines work in a way that depends on an orchestral approach. A plant contains a multitude of different molecules that act synergistically act on targeted elements of the complex cellular pathway [16]. Medicinal plants have been a source of wide variety of biologically active compounds for many centuries and used extensively as crude material or as pure compounds for treating various disease conditions $[18,19]$.

Carrageenan-induced rat paw edema model is a suitable test for evaluating anti-inflammatory drugs, which has frequently been used to assess the anti-edematous effect of the drug [20]. Carrageenan is a strong chemical used for the release of inflammatory and proinflammatory mediators (prostaglandins, leukotrienes, histamine, bradykinin, TNF- $\alpha$, etc.) [21]. Table 3 shows injection of carrageenan into the hind paw induced a progressive edema reaching its maximum at $3 \mathrm{hrs}$. In case of Group 1 animals paw thickness found at prestudy $\mathrm{t}=0$ was $1.56 \pm 0.02 \mathrm{~cm}$, and this remains constant at the end of $24 \mathrm{hrs}$.

Table 1: Phytochemical analysis of ethanolic extract of Z. officinale

\begin{tabular}{ll}
\hline Phytochemicals & Observation \\
\hline Flavonoids & + \\
Saponins & + \\
Tannins & + \\
Terpenoids & + \\
Phenol & + \\
\hline
\end{tabular}

Z. officinale: Zingiber officinale

Table 2: Phytochemical analysis of aqueous extract of Z. officinale

\begin{tabular}{ll}
\hline Phytochemicals & Observation \\
\hline Flavonoids & + \\
Saponins & + \\
Tannins & - \\
Terpenoids & + \\
Phenol & - \\
\hline
\end{tabular}

Z. officinale: Zingiber officinale

Table 3 Anti-inflammatory effect of Z. officinale on carrageenan induced edema on rats

\begin{tabular}{|c|c|c|c|c|c|c|}
\hline \multirow{2}{*}{$\begin{array}{l}\text { Treatment } \\
\text { Groups }\end{array}$} & \multicolumn{6}{|c|}{ Anti-inflammatory $(\mathrm{cm})$} \\
\hline & Prestudy & $1 \mathrm{~h}$ post dose & 2 hrs post dose & 3 hrs post dose & 4 hrs post dose & 24 hrs post dose \\
\hline Group 1 & $1.56 \pm 0.02$ & $1.54 \pm 0.02$ & $1.56 \pm 0.02$ & $1.54 \pm 0.02$ & $1.56 \pm 0.02$ & $1.56 \pm 0.02$ \\
\hline Group 2 & $1.56 \pm 0.04$ & $2.18 \pm 0.06^{\mathrm{a}}$ & $3.16 \pm 0.05^{a}$ & $3.06 \pm 0.05^{\mathrm{a}}$ & $2.66 \pm 0.05^{a}$ & $2.1 \pm 0.09^{a}$ \\
\hline Group 3 & $1.56 \pm 0.04$ & $2.28 \pm 0.10^{\mathrm{a}}$ & $2.1 \pm 0.10^{\mathrm{a}}$ & $1.82 \pm 0.04^{\mathrm{b}}$ & $1.64 \pm 0.06$ & $1.54 \pm 0.04$ \\
\hline Group 4 & $1.60 \pm 0.07$ & $2.44 \pm 0.10^{\mathrm{a}}$ & $1.8 \pm 0.05$ & $1.80 \pm 0.08^{\mathrm{b}}$ & $1.62 \pm 0.06$ & $1.52 \pm 0.02$ \\
\hline Group 5 & $1.58 \pm 0.04$ & $2.22 \pm 0.09^{a}$ & $1.56 \pm 0.04$ & $1.52 \pm 0.02$ & $1.50 \pm 0.03$ & $1.52 \pm 0.02$ \\
\hline
\end{tabular}

All the values are mean \pm SEM $(n=5) .{ }^{\text {b }}<0.01$ and ${ }^{\mathrm{p}} \mathrm{p}<0.001$ compared to Group I. One-way ANOVA followed by Tukey's post-hoc test was applied. Group 1: Normal control rats, Group 2: Diabetic control rats, Group 3: $200 \mathrm{mg} / \mathrm{kg}$ Z. officinale aqueous extract was administered intraperitoneally, Group 4: $400 \mathrm{mg} / \mathrm{kg}$ Z. officinale aqueous extract was administered intraperitoneally, Group 5: Diclofenac sodium $150 \mathrm{mg} / \mathrm{kg}$ was administered intraperitoneally, Z. officinale: Zingiber officinale 
Group 2 animals had showed an increase in paw thickness at each hour, which was significant $(\mathrm{p}<0.001)$. At $24 \mathrm{hrs}$, the thickness was found to be $2.1 \pm 0.09 \mathrm{~cm}$. The paw thickness of Group 3 animals was $1.56 \pm 0.04 \mathrm{~cm}$ $\mathrm{t}=0 \mathrm{hr}$, which showed a mild increase at the end of the first hour, that is, $2.28 \pm 0.010 \mathrm{~cm}$. At the end of $24 \mathrm{hrs}$, it decreased to $1.54 \pm 0.04 \mathrm{~cm}$ at $(\mathrm{p}<0.001)$, respectively. Group 4 animals showed an increase up to the $1^{\text {st }} \mathrm{hr} .2 .44 \pm 0.10 \mathrm{~cm}$ but showed a decrease in the paw thickness at the end of 24 hrs. From these findings, Groups 3 and 4 indicate a significant decrease in paw thickness as compare to the control Group 1 $(\mathrm{p}<0.001)$. Group 5 which received $150 \mathrm{mg} / \mathrm{kg}$ diclofenac sodium shows a significant decrease in paw thickness at $2 \mathrm{hrs}, 3 \mathrm{hrs}, 4 \mathrm{hrs}$ and also 24 hrs as compared to the control Group $1(\mathrm{p}<0.001)$.

\section{CONCLUSION}

The above results indicate that aqueous extracts of $Z$. officinale have significantly decreased the carrageenan-Induced inflammation and related paw edema in our study on SD rats.

\section{REFERENCES}

1. Mahat M, Patil B. Evaluation of anti-inflammatory activity of methanol extract of Phyllanthus amarus in experimental animal models. Indian J Pham Sci 2007;69:33-6.

2. Amdekar S, Roy P, Singh V, Kumar A, Singh R, Sharma P. Antiinflammatory activity of lactobacillus on carrageenan-induced paw Edema in male Wistar rats. Int J Inflam 2012;2012:752015.

3. Tiwari BK, Khosa RL. Evaluation of the hepatoprotective and antioxidant effect of Berberis asiatica against experimentally induced liver injury in rats. Int J Pharm Pharm Sci 2010;2:92-7.

4. Jeena K, Liju VB, Kuttana R. Antitumor and cytotoxic activity of ginger essential oil (Zingiber officinale Roscoe). Int J Pharm Pharm Sci 2015;7:341-4.

5. Rohini K, Srikumar PS, Mahesh KA. A study on the relationship between calcium, oxidative stress and immune response in pulmonary tuberculosis patients. J Chem Biol Phys Sci Sec B 2015;5(1):378-83.

6. Rohini K, Srikumar PS, Saxena J, Mahesh KA. Alteration in the levels of micronutrients in tuberculosis patients. Int $\mathrm{J}$ Biol Med Res 2013;4(1):2958-61.
7. Sosa S, Balick MJ, Arvigo R, Esposito RG, Pizza C, Altinier G, et al. Screening of the topical anti-inflammatory activity of some Central American plants. J Ethnopharmacol 2002;81:211-5.

8. Roy P, Amdekar S, Kumar A, Singh V. Preliminary study of the antioxidant properties of flowers and roots of Pyrostegia venusta (Ker Gawl) Miers. BMC Complement Altern Med 2011;11:69.

9. Rohini K, Srikumar PS. Therapeutic role of coumarins and coumarinrelated compounds. J Thermodyn Catal 2014;5(2):130.

10. Evans WC, Trease GE. Pharmacognosy. $16^{\text {th }}$ ed. Edinburgh: Saunders Elsevier; 2002. p. 289-92.

11. Majeed AA, Martha T, Khaled K, Tariq M, Muslim A. Biochemical and histopathological toxicity of aqueous ginger extract in female rats. Kuwait J Sci 2003;30:35-48.

12. Lorke D. A new approach to practical acute toxicity testing. Arch Toxicol 1983;54:275-87.

13. Dasilva EJ. Medicinal plants: A re-emerging health aid. Electron J Biotechnol 1999:2:1-2.

14. Boeing H, Bechthold A, Bub A, Ellinger S, Haller D, Kroke A, et al. Critical review: Vegetables and fruit in the prevention of chronic diseases. Eur J Nutr 2012;51:637-63.

15. Shirin AP, Prakash J. Chemical composition and antioxidant properties of ginger root (Zingiber officinale). J Med Plants Res 2010;4:2674-9.

16. Bhargava S, Dhabhai K, Batra A, Sharma A, Malhotra B. Zingiber Officinale: Chemical and phytochemical screening and evaluation of its antimicrobial activities. J Chem Pharm Res 2012;4:360-4.

17. Kumar SP, Rahul B, Sumit V, Rashmi A. Phytochemical investigation of ethanolic extract of piper Nicrum, Zingiber officinale and Allium sativum and spectrophotometric detection of Piperine, Gingerol and Allicin. Int Res J Pharm 2014;11:814-6.

18. Durmowicz AG, Stenmark KR. Mechanisms of structural remodeling in chronic pulmonary hypertension. Pediatr Rev 1999;20:e91-e102.

19. Arif T, Bhosale JD, Kumar N, Mandal TK, Bendre RS, Lavekar GS, et al. Natural products - antifungal agents derived from plants. J Asian Nat Prod Res 2009;11:621-38

20. Raji Y, Udoh U, Oluwadara O, Akinsomisoye O, Awobajo O. Anti-inflammatory and analgesic properties of the rhizome extract of Zingiber officinale. Afr J Biomed Res 2002;5:121-4.

21. Anosike CA, Obidoa O, Ezeanyika LU, Nwuba MM. Antiinflammatory and anti-ulcerogenic activity of the ethanol extract of ginger (Zingiber officinale). Afr J Biochem Res 2010;3:379-84. 